\title{
Leptin G-2548A Promoter Polymorphism is Associated with Increased Plasma Leptin and BMI in Brazilian Women
}

\begin{abstract}
Variants in leptin gene ( $L E P)$ have been implicated in the pathogenesis of obesity. The relationship between LEP G-2548A polymorphism and obesityrelated traits was evaluated in a sample of Brazilian women $(n=228)$ who were randomly selected from two clinical centers in Sao Paulo city. Blood samples were collected for DNA extraction, plasma leptin and serum lipids measurements. LEP G-2548A genotypes were identified by a PCR- RFLP strategy using the endonuclease Alw44I. LEP G-2548A was associated with obesity after adjustment for covariates (age, hypertension, coronary artery disease, smoking and physical activity). Women carrying $\mathrm{G}$ allele had a four times higher risk of obesity than the A allele carriers (OR: 4.11, CI95\%: 1.06-15.90, $p=0.041$ ). G allele was also related to increased plasma leptin ( $p$ $=0.024)$ and body mass index $(p=0.027)$. Hypertension, hyperglycemia, dyslipidemia and coronary artery disease were associated with obesity. However LEP G-2548A polymorphism was not related to these variables. All together these data suggest that $L E P$ G-2548A polymorphism has an important role in regulating plasma leptin levels and body mass index in women. (Arq Bras Endocrinol Metab 2008; 52/4:611-616)
\end{abstract}

Keywords: Leptin; Gene polymorphism; Body mass index; Obesity; PCR-RFLP.

\section{RESUMO}

Polimorfismo do Promotor do Gene da Leptina está Associado ao Aumento de Leptina Plasmática e IMC em Mulheres Brasileiras.

Variantes no gene da leptina ( $L E P)$ foram implicados na patogênese da obesidade. A relação entre o polimorfismo $L E P$ G-2548A e as características relacionadas com a obesidade foram avaliadas em mulheres brasileiras $(n=228$ ), que foram selecionadas randomicamente de dois centros de pesquisa clínica na cidade de São Paulo. As amostras de sangue foram coletadas para extração de DNA e determinações de leptina plasmática e lipídeos séricos. Os genótipos do LEP G-2548A foram identificados pela estratégia de PCR-RFLP, empregando a endonuclease Alw44I. O polimorfismo $L E P$ G-2548A foi associado com obesidade, após ajuste para as covariáveis: idade, hipertensão, doença arterial coronariana, tabagismo e atividade física. Mulheres com alelo $G$ tiveram quatro vezes maior risco de obesidade que as portadoras do alelo A (OR: 4,11, CI95\%: 1,06-15,90; $p=0,041$ ). O alelo $\mathrm{G}$ também foi relacionado com leptina plasmática $(p=0,024)$ e o índice de massa corporal $(p=0,027)$ aumentado. A hipertensão, a hiperglicemia, a dislipidemia e a doença arterial coronariana foram associadas com obesidade. Entretanto, o polimorfismo LEP G-2548A não foi relacionado com essas variáveis. Os resultados deste estudo são sugestivos de que o polimorfismo LEP G-2548A tem papel importante na regulação da leptina plasmática e no índice de massa corporal em mulheres. (Arq Bras Endocrinol Metab 2008; 52/4:611-616)

Descritores: Leptina; Polimorfismo genético; Índice de massa corporal; Obesidade; PCR-RFLP. artigo original

\author{
HamiLTON M. HINUY \\ Mario H. HiRATA \\ NEUSA FORTI \\ JAYME DIAMENT \\ MARCELO F. SAMPAIO \\ DikRan ARMAGaniJan \\ LUIS A. SALAZAR \\ Rosario D. C. HiRata
}

Faculdade de Ciências

Farmacêuticas da Universidade de São Paulo (USP), SP, Brasil $(\mathrm{HMH}, \mathrm{MHH}, \mathrm{RDCH})$; Instituto do Coração da Faculdade de Medicina (InCor-FM) da USP, São Paulo, SP, Brasil (NF, JD); Instituto Dante Pazzanese de Cardiologia de São Paulo, SP, Brasil (MFS, DA); Facultad de Medicina da Universidad de La Frontera, Temuco, Chile (LAS).

Recebido em 10/1/2008 Aceito em 6/3/2008 


\section{INTRODUCTION}

T he prevalence of obesity is increasing in most of industrialized countries and has become an important issue of public health. Excessive bodyweight is considered the sixth most important risk factor contributing to the overall burden of disease worldwide (1). Obesity has a complex pathogenesis that results from interactions between genetic and environmental factors that lead to the malfunction of several signaling peptides, which are involved in body energy balance and nutritional status $(2,3)$.

Leptin is a metabolic and neuroendocrine hormone produced and released mainly by adipocytes $(4,5)$. It has several systemic effects such as body mass control, reproduction, angiogenesis, immunity, wound healing, bone remodelling and cardiovascular function $(4,6)$. Plasma leptin concentration is proportional to body adiposity and is markedly increased in obese individuals (4).

Several studies have suggested that variants in the leptin gene $(L E P)$ may be important to the pathophysiology of human obesity $(7,8)$. A common single nucleotide polymorphism within the 5 ' promoter region (G-2548A) of LEP has been associated with variations in plasma leptin and body mass index (BMI) in obese individuals (9-11). It has been shown that the G-2548A LEP polymorphism influences leptin expression, possibly at the transcriptional level, and therefore also adipose secretion levels of the hormone (12).

In this study, the influence of the LEP G-2548A polymorphism on plasma leptin and obesity-related traits was evaluated in a sample of Brazilian women.

\section{SUBJECTS AND METHODS}

\section{Study group}

Blood samples were obtained from 228 unrelated Brazilian women, who were selected from Instituto do Coração/Faculdade de Medicina/Universidade de Sao Paulo (FMUSP) and Instituto Dante Pazzanese de Cardiologia (IDPC), Sao Paulo, Brazil. Although these individuals were declared non-Africans by physical evaluation, a lack of relationship between color and genomic ancestry have been found in Brazilian samples (13). The study was previously approved by the FMUSP and IDPC Ethical Committees and written consent was obtained from each participant.

Anthropometrics measurements, such as BMI, waist circumference (WC) and waist-to-hip ratio (WHR) were taken from each participant (14). Systolic/diastolic blood pressure was measured in supine position after resting for $30 \mathrm{~min}$. Based on World Health Organization recommendations, people with BMI higher than $30 \mathrm{~kg} /$ $\mathrm{m}^{2}$ were classified as obese (15) and those with systolic/ diastolic blood pressure over 140/90 $\mathrm{mmHg}$ or under lowering-pressure therapy were considered hypertensive (16). The presence of coronary artery disease (CAD) was investigated by coronary angiography.

\section{Biochemical analyses}

A 12-hour fasting blood sample was collected from each participant for serum lipids, plasma glucose and leptin determinations. Glucose, triglycerides, total cholesterol and high-density lipoprotein (HDL) cholesterol were measured by enzymatic-colorimetric assays using a Roche-Hitachi 912 automated analyzer (Hitachi, Nakakojo, Japan). Low-density lipoprotein (LDL) and very low-density lipoprotein (VLDL) cholesterol were calculated by Friedewald formulae (17). Plasma leptin was determined by ELISA method (Alexis Biochemical/Vendor BioAgency, Sao Paulo, Brazil). The Atherogenic Index of Plasma (AIP) calculated as $\log$ (triglyceride/HDL cholesterol) and the apolipoprotein B/apolipoprotein AI (apoB/ApoAI) ratio were also estimated $(18,19)$.

\section{DNA extraction and LEP G-2548A genotyping}

Genomic DNA was extracted from $1 \mathrm{~mL}$ EDTA-anticoagulated whole blood by a salting-out method (20). G-2548A LEP polymorphism was detected by a PCRRFLP strategy using the endonuclease Alw44I (Fermentas, Vilnius, Lithuania). The primers used in PCR assays were designed based on the LEP promoter sequence previously described (21). The forward primer ( 5 ' - CTTTTGTTTTGTTTTGCGACAGGGG TGC-3') creates a recognition site for Alw44I endonuclease that allows the detection of the A allele. The reverse primer (5'-GCTCCCTTTGCCCGACCCCG-3') generates a PCR product with a constitutive site for $A l w 44$ I that is useful as an internal control for restrictive reaction.

Genomic DNA (50 ng) was amplified in $50 \mu \mathrm{L}$ assays containing primers $200 \mathrm{nmol} / \mathrm{L}$ (Life Technologies, Sao Paulo, Brazil), dNTPs $200 \mu \mathrm{mol} / \mathrm{L}$ (Amersham Bioscience, USA), DNA polymerase $1 \mathrm{U}$ and PCR buffer $[50 \mathrm{mM}$ $\mathrm{KCl}, 2 \mathrm{mmol} / \mathrm{L} \mathrm{MgCl}_{2}, 20 \mathrm{mmol} / \mathrm{L}\left(\mathrm{NH}_{4}\right)_{2} \mathrm{SO}_{4}, 75$ mmol/L Tris-HCl, pH 9,0] (Biotools, Madrid, Spain). 
PCR assays were carried out in a PTC-200 ${ }^{\mathrm{TM}}$ Thermal Cycler (M\&J Research, Inc., Watertown, USA). After initial denaturation at $96^{\circ} \mathrm{C}$ for $3 \mathrm{~min}$, amplification was performed using 30 cycles at $96^{\circ} \mathrm{C}$ for $30 \mathrm{~s}$ and $70^{\circ} \mathrm{C}$ for $90 \mathrm{~s}$, followed by final extension at $72^{\circ} \mathrm{C}$ for $10 \mathrm{~min}$. PCR products were incubated with $4 \mathrm{U}$ of $A l w 44 \mathrm{I}$ (Fermentas, Vilnius, Lithuania) at $37^{\circ} \mathrm{C}$ for $2 \mathrm{hs}$. PCR and restriction products were separated on $2 \%$ agarose gel electrophoresis at $100 \mathrm{~V}$ for $45 \mathrm{~min}$ and analyzed under UV light after ethidium bromide staining.

The accuracy of the genotyping was evaluated by performing duplicate analysis of $20 \%$ samples randomly selected. Moreover, a heterozygous LEP G-2548A polymorphism sample (control sample) was included in each run.

\section{Statistical analysis}

Categorical variables were compared by chi-square test. The agreement of genotypes frequencies with HardyWeinberg equilibrium expectations was tested using the chi-square test. Continuous variables were presented as means \pm SD and compared by $t$-test. Variables without normal distribution (BMI, WC, leptin, glucose and lipid profile) were log transformed for analysis. Relationships between the genotypes and categorical variables (obesity, diabetes, hypertension, smoking, physical activity and CAD) were evaluated by either the chi-square test or Exact Fisher test.
Logistic Regression Analysis was used to establish correlations between obesity and independent variables. Multivariate Logistic Regression Analysis with Stepwise criteria for variable selection was used to establish correlation with obesity. The relation between LEP G-2548A alleles and the dependent variables (BMI, WC and WHR) was evaluated by Univariate Linear Regression Analysis. The results of these analyses were adjusted for the covariates: age, hypertension, diabetes, smoking, physical activity and CAD. The main predictors in the linear model were the LEP alleles. Statistical tests were performed by SAS System for Windows software version 8.02 (SAS Institute Inc, 1999-2001, Cary, NC, USA). Significance was assumed for $P<0.05$.

\section{RESULTS}

Anthropometric and clinical data of women are shown in Table 1. Obese individuals exhibited mean age, BMI, waist circumference, waist-hip ratio and plasma leptin values higher than the non-obese group $(p<0.05)$. Hypertension, diabetes, CAD, physical activity and menopause were also more frequent in the obese group $(p$ $<0.05$ ). As expected, G-2548A LEP genotype distributions did not differ from those expected under HardyWeinberg equilibrium (data not shown). There was no difference in genotype and allele frequencies between obese and non-obese groups $(p=0.304)$.

Table 1. Anthropometric, clinical, and LEP G-2548A polymorphism data in women.

\begin{tabular}{|c|c|c|c|}
\hline & Obese (100) & Non-obese (128) & $P$ value \\
\hline Age (yrs) & $52 \pm 11$ & $47 \pm 13$ & $<0.001$ \\
\hline $\mathrm{BMI}\left(\mathrm{kg} / \mathrm{m}^{2}\right)^{*}$ & $34.6 \pm 4.1$ & $23.7 \pm 2.8$ & $<0.001$ \\
\hline Waist circumference* & $106.4 \pm 9.2$ & $84.8 \pm 10.9$ & $<0.001$ \\
\hline Waist-hip ratio & $0.90 \pm 0.05$ & $01.85 \pm 0.07$ & $<0.001$ \\
\hline Leptin* & $41.9 \pm 19.6$ & $15.7 \pm 13.1$ & $<0.001$ \\
\hline CAD & $14 \%$ & $1 \%$ & 0.004 \\
\hline Diabetes & $23 \%$ & $0 \%$ & $<0.001$ \\
\hline Hypertension & $72 \%$ & $10 \%$ & $<0.001$ \\
\hline Physical activity & $79 \%$ & $63 \%$ & 0.032 \\
\hline Menopause & $67 \%(67)$ & $47 \%(60)$ & 0.01 \\
\hline Smoking & $35 \%$ & $27 \%$ & 0.340 \\
\hline \multicolumn{4}{|l|}{ LEP G-2548A } \\
\hline Genotype GG & $40.0 \%$ & $30.5 \%$ & 0.304 \\
\hline Genotype GA & $48.0 \%$ & $53.9 \%$ & \\
\hline Genotype AA & $12.0 \%$ & $15.6 \%$ & \\
\hline G allele & $64 \%$ & $58 \%$ & 0.133 \\
\hline
\end{tabular}

Number of individuals in parenthesis. Individuals with $\mathrm{BMI} \geq 30 \mathrm{~kg} / \mathrm{m}^{2}$ were classified as obese (15) and those with systolic/diastolic blood pressure over to $140 / 90 \mathrm{mmHg}$ or under anti-hypertensive therapy were considered hypertensive (16); Continuous variables are presented as mean \pm SD and were compared by $t$-test. Categorical variables were compared by qui-square or Exact Fisher test; (*) Values were log transformed. 
Univariate logistic regression analysis showed that women with hypertension and CAD had high risk (eleven times) of obesity (Table 2 ). Increased age, plasma leptin and glucose, and serum triglycerides, VLDL cholesterol, apoB, apoB/ApoAI ratio and AIP were also associated with obesity in our sample $(p<0.001)$.

Table 2. Univariate logistic regression analysis of the variables associated with obesity.

\begin{tabular}{|c|c|c|c|}
\hline Variables & P value & Odds Ratio & $95 \%$ Confidence Interval \\
\hline CAD & 0.021 & 11.61 & $1.45-93.28$ \\
\hline Hypertension & $<0.001$ & 24.51 & $9.63-62.40$ \\
\hline Physical activity & 0.034 & 2.23 & $1.06-4.68$ \\
\hline Age & $<0.001$ & 1.04 & $1.02-1.07$ \\
\hline Leptin & $<0.001$ & 1.10 & $1.07-1.13$ \\
\hline Glucose & $<0.001$ & 1.1 & $1.06-1.14$ \\
\hline Total cholesterol & 0.066 & 1.01 & $0.99-1.01$ \\
\hline LDL cholesterol & 0.056 & 1.01 & $0.99-1.01$ \\
\hline HDL cholesterol & $<0.001$ & 0.96 & $0.94-0.98$ \\
\hline VLDL cholesterol & $<0.001$ & 1.08 & $1.05-1.11$ \\
\hline Triglycerides & $<0.001$ & 1.01 & $1.01-1.02$ \\
\hline ApoAl & 0.057 & 0.99 & $0.98-1.01$ \\
\hline ApoB & $<0.001$ & 1.03 & $1.1-1.04$ \\
\hline ApoB/ApoAl ratio & $<0.001$ & 36.69 & $6.28-214.28$ \\
\hline AIP & $<0.001$ & 30.28 & $9.19-99.74$ \\
\hline LEP G allele adjusted* & 0.041 & 4.11 & $1.06-15.90$ \\
\hline
\end{tabular}

$\left({ }^{\star}\right)$ Adjusted to the covariates: age, hypertension, CAD, smoking and physical activity.

ApoAl, apolipoprotein I; ApoB, apolipoprotein B; AIP, atherogenic index of the plasma; CAD, coronary artery disease; HDL, high-density lipoprotein; LDL, low-density lipoprotein; VLDL, very low-density lipoprotein.

Analyses of LEP G-2458A polymorphism showed that women carrying $-2548 \mathrm{G}$ allele (GG genotype) had four times higher risk of obesity (OR: 4.11, 95\% CI: $1.06-15.90)$ than the -2548 A allele carriers $(p=$ $0.041)$ when the variable was adjusted to the covariates age, hypertension, CAD, smoking and physical activity
(Table 2). Univariate linear regression analyses showed that $-2548 \mathrm{G}$ allele is associated with plasma leptin $\left(\mathrm{R}^{2}\right.$ : $2.70, p=0.024)$ and BMI $\left(\mathrm{R}^{2}: 2.07, p=0.027\right)$ but not with waist circumference or waist-hip ratio (Table 3 ). G allele contributes to the increase in $0.18 \mathrm{log}$ units for leptin and $0.04 \log$ units for BMI.

Table 3. Univariate linear regression analysis of the variables associated with LEP G-2548A polymorphism.

\begin{tabular}{|c|c|c|c|c|}
\hline Dependent variables & LEP G-2548A & $P$ value & $\mathbf{R}^{2}(\%)$ & Estimate (SE) \\
\hline \multirow[t]{2}{*}{ Body mass index } & A allele & 0.394 & 0.31 & $-0.01(0.01)$ \\
\hline & $G$ allele & 0.027 & 2.07 & $0.04(0.02)$ \\
\hline \multirow[t]{2}{*}{ Waist circumference } & A allele & 0.523 & 0.18 & $-0.01(0.01)$ \\
\hline & G allele & 0.167 & 0.85 & $0.02(0.01))$ \\
\hline \multirow[t]{2}{*}{ Waist-hip ratio } & A allele & 0.900 & 0.01 & $-0.01(0.01)$ \\
\hline & G allele & 0.790 & 0.04 & $0.01(0.01)$ \\
\hline \multirow[t]{2}{*}{ Plasma Leptin } & A allele & 0.876 & 0.01 & $0.01(0.06)$ \\
\hline & G allele & 0.024 & 2.74 & $0.18(0.08)$ \\
\hline
\end{tabular}

Variables were adjusted to the covariates: age, hypertension, diabetes, CAD, smoking and physical activity. Estimate indicates variation of log values.

Results from multivariate logistic regression analysis with Stepwise criterion for variable selection indicate that the risk of obesity was nine times higher in hypertensive women (O.R.: 9.06, 95\% Cl: 2.67-30.80, p < 0.001) (data not shown). Other predictors for obesity found in our sample are increased plasma leptin (O.R.: 1.08, 95\% Cl: 1.05-1.12, $p<0.001$ ) and serum apoB (O.R.: 1.03, 95\% Cl: 1.01-1.05, $p<0.001)$, and reduced HDL cholesterol (O.R.: 0.93, 95\% Cl: 0.89-0.97). 


\section{DISCUSSION}

The frequency of the LEP -2548G allele (64\%) observed in Brazilian obese women was similar to that found in European overweight women and obese girls $(10,11)$, as well as in North Americans (22). Our results clearly demonstrate that women carrying $-2548 \mathrm{G}$ allele have at least four times more risk of obesity than non-carriers suggesting that LEP G-2548A polymorphism is a strong obesity predictor.

An association of LEP G-2548A polymorphism and increased BMI was also found in overweight Europeans (10) and in a sample of Taiwanese Aborigines with extreme obesity (23). In addition, common variants located in the 5 'region of the $L E P$, including G2548 A, were associated with increased BMI in men (24). On the other hand, other studies have failed to demonstrate association among these polymorphisms and obesity or increased BMI (25-28).

The relationship between $L E P-2548 \mathrm{G}$ allele and increased plasma leptin concentrations found in this sample was also described in obese and diabetic individuals from European and Asian populations (11,29). This allele was associated with plasma free leptin levels through an interaction with adiposity and gender in healthy individuals from Greece (30). On the other hand, -2458AA genotype was associated with increased plasma leptin in obese individuals and in men from France cohorts $(9,10)$. These different results may be due to interactions of G-2548A polymorphism with other variants in leptin and/or leptin receptor genes, as well as other variables such as gender, sample size and population, or the model used in genetics analyses.

The G-2548A polymorphism is located at the 5'end of the promoter region of $L E P$ and it has been suggested that this remote region may contain inhibitory elements for transcription in adipocytes (21). Even though this polymorphism is close to a SP-1 transcription factor binding site, as well as two repetitive sequences MERI l and Alu that maybe regulate $L E P$ transcription, the effect of the $G$ to $A$ substitution at -2548 nucleotide in leptin expression remains to be elucidated.

In this study, obesity was associated with hypertension and other CAD-related risk factors such as advanced age, diabetes, dyslipidemia, smoking, and increased apoB/apoAI ratio and AIP. However, our data do not support association of the LEP G-2548A with CAD, as it has been recently demonstrated for the LEP-tet mi- crosatellite polymorphism in Italians and Brazilians $(31,32)$.

Positive correlations between leptin and glucose, lipids, apoB/apoAI ratio and AIP values suggest its possible role as risk factor for CAD. A relationship among leptin, adiponectin, and abdominal obesity with cardiovascular risk assessed by apoB/ApoI ratio was recently demonstrated in Asian Indian and Caucasian populations (33). Leptin exerts many potentially atherogenic effects such as induction of endothelial dysfunction, stimulation of inflammatory reaction, oxidative stress, decrease in paraoxonase activity, platelet aggregation, migration, hypertrophy and proliferation of vascular smooth muscle cells (34). These effects may contribute to the pathogenesis of hypertension, atherosclerosis, and left ventricular hypertrophy frequently associated with obesity $(35,36)$.

In conclusion, LEP G-2548A polymorphism is an important predictor for increased plasma leptin and BMI in Brazilian women and it maybe a useful marker for obesity-related risk in this population.

\section{ACKNOWLEDGEMENTS}

This study was supported by FAPESP (Grant no. 2001/10708-3), Sao Paulo, SP, Brazil. Thanks to Dr. Sergio Diogo Gianinni (in memoriam) for selecting patients, and Nivea A. C. Salvarani and Carlos Eduardo Pinto for their assistance in sample collection. H. M. Hinuy was recipient of a fellowship from FAPESP (Grant no. 2000/11700-3), Sao Paulo, SP, Brazil. M.H. Hirata and R.D.C. Hirata are coworkers from CNPq, Brasilia, DF, Brazil.

\section{REFERENCES}

1. Haslam DW, James WP. Obesity. Lancet. 2005;366:1197-209.

2. Cummings DE, Schwartz MW. Genetics and pathophysiology of human obesity. Annu Rev Med. 2003;54:453-71.

3. Farooqi S, O'Rahilly S. Genetics of obesity in humans. Endocr Rev. 2006;27:710-8.

4. Considine RV, Sinha MK, Heiman ML, Kriauciunas A, Stephens TW, Nyce MR, et al. Serum immunoreactive-leptin concentrations in normal-weight and obese humans. N Engl J Med. 1996;334:292-5.

5. Considine RV. Human leptin: an adipocyte hormone with weight-regulatory and endocrine functions. Semin Vasc Med. 2005;5:15-24.

6. Fruhbeck G. Intracellular signalling pathways activated by leptin. Biochem J. 2006;393:7-20. 
7. Paracchini V, Pedotti P, Taioli E. Genetics of leptin and obesity: a HuGE review. Am J Epidemiol. 2005;162:101-4.

8. Rankinen T, Zuberi A, Chagnon YC, Weisnagel SJ, Argyropoulos G, Walts B, et al. The human obesity gene map: the 2005 update. Obesity (Silver Spring). 2006;14:529-644.

9. Mammes O, Betoulle D, Aubert R, Giraud V, Tuzet S, Petiet A, et al. Novel polymorphisms in the $5^{\prime}$ region of the LEP gene association with leptin levels and response to low-calorie diet in human obesity. Diabetes. 1998;47:487-9.

10. Mammes $O$, Betoulle D, Aubert $R$, Herbeth B, Siest G, Fumeron $\mathrm{F}$. Association of the G-2548A polymorphism in the $5^{\prime}$ region of the LEP gene with overweight. Ann Hum Genet. 2000;64:391-4.

11. Le Stunff C, Le Bihan C, Schork NJ, Bougneres P. A common promoter variant of the leptin gene is associated with changes in the relationship between serum leptin and fat mass in obese girls. Diabetes. 2000;49:2196-200.

12. Hoffstedt J, Eriksson P, Mottagui-Tabar S, Arner P. A polymorphism in the leptin promoter region (-2548 g/a) influences gene expression and adipose tissue secretion of leptin. Horm Metab Res. 2002;43:355-9.

13. Parra FC, Amado RC, Lambertucci JR, Rocha J, Antunes CM, Pena SD. Color and genomic ancestry in Brazilians. Proc Natl Acad Sci U S A. 2003;100:177-82.

14. Lean MEJ, Han TS, Morrison CE. Waist circumference as a measure for indicating need for weight management. Br Med $\mathrm{J}$. 1995;311:158-61.

15. World Health Organization. Obesity: preventing and managing the global epidemic. Report of a WHO consultation. World Health Organ Tech Rep Ser. 2000;894:1-253.

16. Whitworth JA, Chalmers J. World health international organisation society of hypertension (WHO/ISH) hypertension guidelines. Clin Exp Hypertens. 2004;26:747-52.

17. Friedewald WT, Levy RI, Fredrickson DS. Estimation of the concentration of low-density lipoprotein cholesterol in plasma, without use of the preparative ultracentrifuge. Clin Chem. 1972;18:499-502.

18. Dobiasova M, Frohlich J. The plasma parameter log (TG/HDLC) as an atherogenic index: correlation with lipoprotein particle size and esterification rate in apoB-lipoprotein-depleted plasma $\left(\mathrm{FER}_{\mathrm{HDL}}\right.$ ). Clin Biochem. 2001:34:583-8.

19. Walldius $G$, Jungner I, Aastveit $A H$, Holme I, Furberg CD, Sniderman AD. The apoB/apoA-I ratio is better than the cholesterol ratios to estimate the balance between plasma proatherogenic and antiatherogenic lipoproteins and to predict coronary risk. Clin Chem Lab Med. 2004;42:1355-63.

20. Salazar LA, Hirata MH, Cavalli SA, Machado MO, Hirata RDC. Optimized procedure for DNA isolation from fresh and cryopreserved clotted human blood useful in clinical molecular testing. Clin Chem. 1998;44:1748-50.

21. Gong DW, Bi S, Pratley RE, Weintraub BD. Genomic structure and promoter analysis of the human obese gene. J Biol Chem. 1996;271:3971-4.

22. Skibola CF, Holly EA, Forrest MS, Hubbard A, Bracci PM, Skibola DR, et al. Body mass index, leptin and leptin receptor polymorphisms, and non-Hodgkin lymphoma. Cancer Epidemiol Biomarkers Prev. 2004;13:779-86.

23. Wang TN, Huang MC, Chang WT, Ko AM, Tsai EM, Liu CS, et al. G-2548A polymorphism of the leptin gene is correlated with extreme obesity in Taiwanese aborigines. Obesity (Silver Spring). 2006;14:183-7.

24. Jiang Y, Wilk JB, Borecki I, Williamson S, DeStefano AL, Xu G, et al. Common variants in the $5^{\prime}$ region of the leptin gene are associated with body mass index in men from the National Heart, Lung, and Blood Institute Family Heart Study. Am J Hum Genet. 2004;75:220-30.

25. Lucantoni R, Ponti E, Berselli ME, Savia G, Minocci A, Calo G, et al. The A19G polymorphism in the $5^{\prime}$ untranslated region of the human obese gene does not affect leptin levels in severely obese patients. J Clin Endocrinol Metab. 2000;85:3589-91.

26. De Silva AM, Walder KR, Boyko EJ, Whitecross KF, Nicholson G, Kotowicz M, et al. Genetic variation and obesity in Australian women: a prospective study. Obes Res. 2001;9:733-40.

27. Mattevi VS, Zembrzuski VM, Hutz MH. Association analysis of genes involved in the leptin-signaling pathway with obesity in Brazil. Int J Obes Rel Metab Res. 2002;26:1179-85.

28. Portoles O, Sorli JV, Frances F, Coltell O, Gonzalez JI, Saiz C, et al. Effect of genetic variation in the leptin gene promoter and the leptin receptor gene on obesity risk in a population-based case-control study in Spain. Eur J Epidemiol. 2006;21:605-12.

29. Ren W, Zhang SH, Wu J, Ni YX. Polymorphism of the leptin gene promoter in pedigrees of type 2 diabetes mellitus in Chongqing, China. Chin Med J (Engl). 2004;117:558-61.

30. Yiannakouris N, Melistas L, Yannakoulia M, Mungal K, Mantzoros CS. The-2548G/A polymorphism in the human leptin gene promoter region is associated with plasma free leptin levels; interaction with adiposity and gender in healthy subjects. Hormones (Athens). 2003;2 229-36.

31. Porreca E, Di Febbo C, Pintor S, Baccante G, Gatta V, Moretta $V$, et al. Microsatellite polymorphism of the human leptin gene (LEP) and risk of cardiovascular disease. Int J Obes (Lond). 2006;30:209-13.

32. Hinuy HM, Hirata MH, Sampaio MF, Armaganijan D, Salazar LA, Hirata RD. LEP $3^{\prime} H V R$ is associated with obesity and leptin levels in Brazilian individuals. Mol Genet Metab. 2006;89:374-80.

33. Smith J, Al-Amri M, Sniderman AD, Cianflone K. Leptin and adiponectin in relation to body fat percentage, waist to hip ratio and the apoB/apoA1 ratio in Asian Indian and Caucasian men and women. Nutr Metab (Lond). 2006;3:18.

34. Correia ML, Haynes WG. Leptin, obesity and cardiovascular disease. Curr Opin Nephrol Hypertens. 2004;13:215-23.

35. Morse SA, Bravo PE, Morse MC, Reisin E. The heart in obesityhypertension. Expert Rev Cardiovasc Ther. 2005;3:647-58.

36. Beltowski J. Leptin and atherosclerosis. Atherosclerosis. 2006;189:47-60.

\section{Endereço para correspondência:}

Rosario Dominguez Crespo Hirata

Faculdade de Ciências Farmacêuticas da Universidade de São Paulo

Av. Lineu Prestes, 580, B17

05508-900 São Paulo, SP

E-mail: rosariohirata@usp.br 